\title{
Review
}

\section{Conservation and aquaculture of native freshwater prawns: the case of the cauque river prawn Macrobrachium americanum (Bate, 1868)}

\author{
Marcelo García-Guerrero ${ }^{1}$, Rodolfo de los Santos Romero ${ }^{1}$ \\ Fernando Vega-Villasante ${ }^{2} \&$ Edilmar Cortes-Jacinto $^{3}$ \\ ${ }^{1}$ Centro Interdisciplinario de Investigación para el Desarrollo Integral Regional-Instituto Politécnico Nacional \\ (CIIDIR-IPN) Unidad Oaxaca, Santa Cruz Xoxocotlán, Oaxaca, México \\ ${ }^{2}$ Centro de Investigaciones Costeras, El Centro Universitario de la Costa \\ Universidad de Guadalajara Puerto Vallarta, Jalisco \\ ${ }^{3}$ Centro de Investigaciones Biológicas del Noroeste (CIBNOR), La Paz, B.C.S., México \\ Corresponding author: Marcelo U. García-Guerrero (mgarciagu@ipn.mx)
}

\begin{abstract}
Latin America has a high diversity of Macrobrachium prawns, some of them with commercial interest. Among them, the cauque river prawn Macrobrachium americanum is a large prawn of the western coast with commercial value due to its size and taste, but it has been extensively subjected to fishery exploitation, leading to population decline. Cultivation is an option for commercial production and conservation. Some research focused on domestication has been performed. Here, we revise the status of that research and discuss possibilities for sustainable freshwater prawn aquaculture in Mexico and elsewhere in Latin America.
\end{abstract}

Keywords: Macrobrachium americanum, river prawn, production, management, aquaculture.

\section{Conservación y cultivo de especies nativas de langostinos: el caso del cauque Macrobrachium americanum (Bate, 1868)}

\begin{abstract}
RESUMEN. América Latina tiene una gran diversidad de langostinos Macrobrachium, algunos de ellos con interés comercial. Entre ellos, el cauque, Macrobrachium americanum, una especie de la costa occidental de América que tiene valor comercial por su tamaño y sabor, que está ampliamente sujeto a explotación pesquera, que ha causado la disminución de sus poblaciones. El cultivo es una opción para su conservación y producción comercial. En el presente trabajo se revisó el estado de la investigación sobre la especie y se discuten sus posibilidades para la acuicultura sostenible en México y en otros países Latinoamericanos.
\end{abstract}

Palabras clave: Macrobrachium americanum, langostino, producción, manejo, acuiculura.

\section{INTRODUCTION}

Freshwater Macrobrachium prawns are an important product both cultivated and extracted from rivers, mostly in Asia and Latin America (Grave et al., 2008). These prawns can be cultivated in simple facilities using low-cost methods (Valenti \& New, 2000; Wahab et al., 2012). The less intensive farming operations and lower costs of freshwater prawn's production compared to marine shrimp could make their culture an option for sustaining rural cultivation by small-scale farmers and local markets (Valenti \& New, 2000; Kutty, 2005; Martínez-Córdova et al., 2009; Tidwell \& D'Abramo,
2010). There are some successful examples of intense production in several regions of the world (Valenti \& New, 2000; Wahab et al., 2012; Almeida \& MoraesValenti, 2012; Hongtuo et al., 2012; Nair \& Salin, 2012; Na-Nakorn \& Jintasataporn, 2012). In Asia, prawn farming is an important activity in expansion that plays an important role in alleviating poverty, generating employment and foreign currency (Wahab et al., 2012). Its expansion should continue if aquaculture is to satisfy the global demand for food products (Ross et al., 2008; Martínez-Córdova et al., 2009). However, today, expansion relies on a range of aquatic species representing only a small fraction of

Corresponding editor: Erich Rudolph 
those with potential for aquaculture (Ross \& Beveridge, 1995). This is particularly true in the case of Latin American Macrobrachium prawns, since only few species are fished or cultivated. This work discusses the potential for aquaculture of one of them, the cauque prawn (Macrobrachium americanum Bate, 1868; Fig. 1 ), provides information on the research status, and clarifies issues related to its exploitation.

\section{General panorama of prawn culture in Latin America}

Most Latin American countries are multicultural with many human societies still maintaining ancient traditions and having a very high biodiversity in their regions. In these countries, and Mexico in particular, ancient tradition related to the exploitation criteria of fisheries are still subjected to ancient methods, as they are part of strong traditional roots. Because of this, in addition to poverty issues, some of these fishery resources in the region are over-exploited and seem to be causing an adverse impact on particular populations. Freshwater prawns are not exempt of these effects. Most commercially available prawns come from informal fisheries since aquaculture is not practiced due to the lack of proper cultivation techniques for native species and the lack of sufficient research. Therefore, in Latin America this enterprise has failed to expand. This can be improved with the generation of research and proper management policies (Wahab et al., 2012; García-Guerrero et al., 2013).

\section{Why cultivate native species?}

In Mexico, the Comision Nacional para la Biodiversidad (CONABIO) identified four priorities related to conservation of live resources: a) protection and conservation, b) evaluation of biodiversity, c) planning and management of information, and d) diversification of resources use. The last statement involves cultivation of native species under sustainable aquaculture to minimize impacts caused by introduced species (Ross et al., 2008; Somoza \& Ross, 2011). To be successful, farming should have a constant, readily available and affordable seed supply and, as far as possible, mostly of native species, including prawns. Native species are already adapted; there would be no heating expenses or costly facilities so production costs will be low. It is easy to avoid inbreeding problems by incorporating wild individuals (García-Guerrero \& Apun-Molina, 2008; Hongtuo et al., 2012). Their cultivation could be an income source to local settlements and may provide relief to wild populations impacted by overexploitation and pollution (Schwantes et al., 2009). The economic and environmental requirements of each country would determine if cultivation is profitable and whether it will reach markets as a live, fresh-killed, processed, or frozen product.

In contrast, exotic species often bring complications because they may not be adapted to exotic weather or water conditions and may not resist local diseases or incur in inbreeding or disease problems due to stocks degradation (Nair \& Salin, 2012; Na-Nakorn \& Jintasataporn, 2012). In addition, foreign species frequently introduce new pathogens or parasites (Ross et al., 2008). Since M. rosenbergii is exotic in Latin America and production of this species has declined in most of the continent, cultivation techniques for native species are being considered (Valenti \& MoraesRiodades, 2004; Goda, 2008; Vega-Villasante et al., 2011). These studies have investigated Latin American prawn species with aquaculture potential. Good examples are known for M. amazonicum, M. tenellum and $M$. americanum

\section{The Macrobrachium americanum case}

This prawn is distributed along the Pacific slope of America between Baja California (Mexico) and Peru, as well as at Cocos and Galapagos Islands (Holthius, 1980). It is still present in most coastal areas where the rivers empty into lagoons and then to the ocean (Hernández et al., 2007). In the past, it was collected in areas far from coastal plains and it was widely present even in habitats where the amount of water is minimal during dry seasons, since it is able to overcome natural barriers. However, current human activities are contributing to a severe decrease of its populations. It has become scarcer every year, and the current status of its populations is unknown in most of its distribution range. In recent years, there has been increased interest in commercial farming of this species among producers and research groups. However, since there are no techniques for its culture its farming cannot start in its native region in the near future.

\section{General biology}

M. americanum is a species with a wide distribution potential either along the coast or into the continental waters including freshwater lakes, reservoirs and rivers in tropical and subtropical areas of western Mexico (Hernandez et al., 2007), as this species can reach large distances from the coast (more than $150 \mathrm{~km}$ ). It could become a good biological index of ecological fitness, considering that domestic, agricultural, industrial and human wastes cause pollution at different scales and may easily kill larvae and juveniles that are very sensitive to small concentrations of pesticides, heavy metals (Piyan et al., 1985; Adhicari et al., 2007), and other anthropogenic pollutants (Shinn-Pyng et al., 2005). Females can spawn several times each year and 


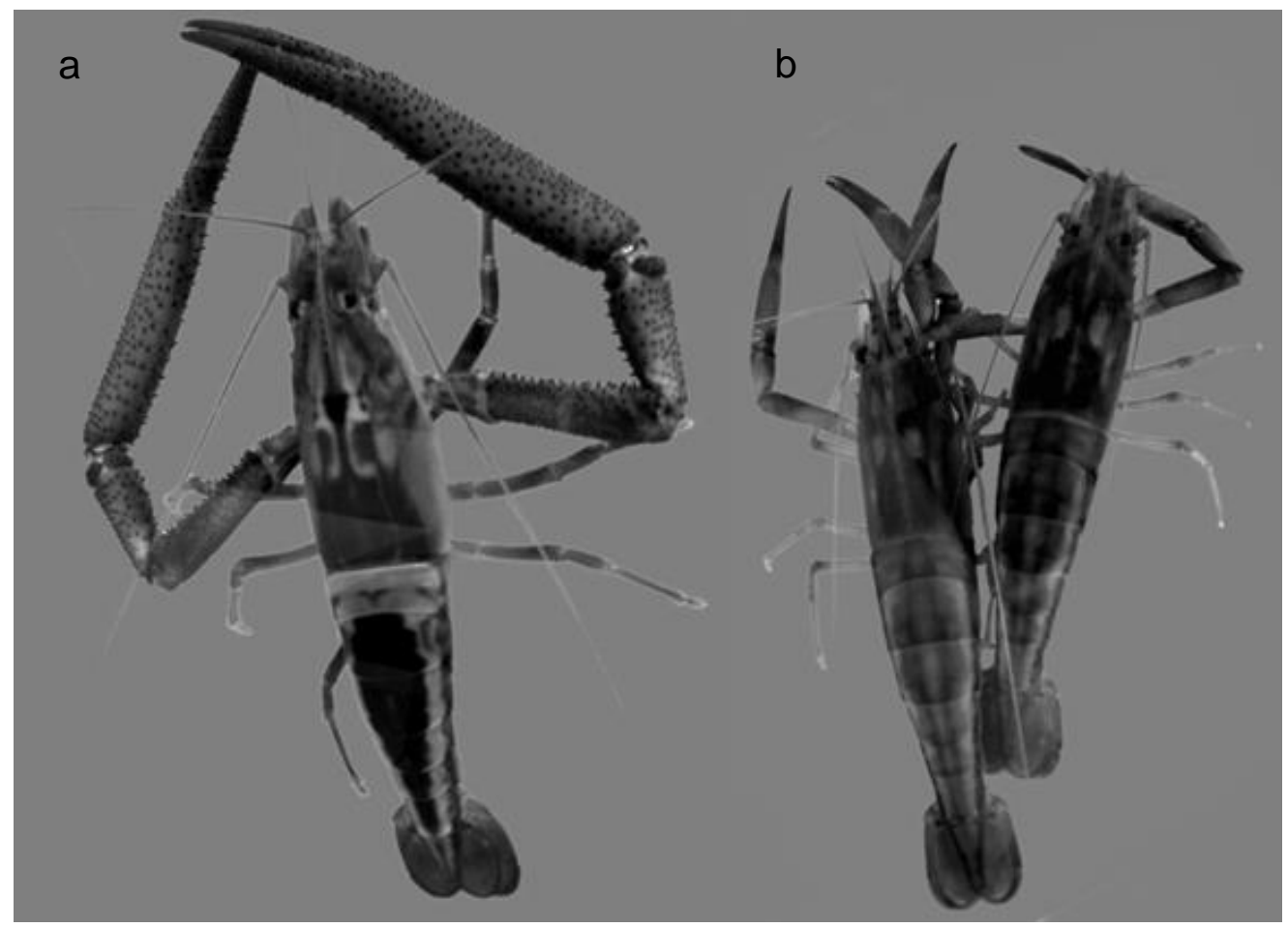

Figure 1. Macrobrachium americanum prawns. a) Male, b) females.

produce from some hundreds to almost three thousand eggs at each spawning (García-Guerrero \& Hendrickx, 2009). Males may grow to about $29 \mathrm{~cm}$ in total length; the reproductive season occurs from May-September (García-Guerrero, 2009). In the regions where these prawns still exist, river conditions change intensely with the season (high water flow from May to October and low water flow from November to April). This phenomenon allows its reproduction, but increases its exposure to fishing (García-Guerrero et al., 2013). Its larval development involves fifteen larval stages that need salty water to survive (Holtschmit \& Pfeiler, 1984; Yamasaki-Granados et al., 2013). As in most Macrobrachium species, wild females breed and spawn in freshwater but planktonic larvae must grow in brackish water. At juvenile stage, they become benthonic and start migrating into inland freshwater (Horne \& Besser, 1977; Bauer, 2011). Based on previous studies, it is known that juveniles and adults are easy to feed in captivity, since they can consume all kinds of food with animal protein, mainly commercial shrimp pellets, fish, or squid meat (García-Guerrero \& Apun-Molina, 2008). Few formal general biology studies have been done in this species. García-Guerrero et al., (2011) studied how $\mathrm{O}_{2}$ consumption was related to size and water temperature highlighting the negative effect of low oxygen concentrations. García-Guerrero $\&$ Hendrickx (2009) described embryonic development and García-Guerrero $(2009,2010)$ and determined variations in the proximate composition of eggs incubated at different temperatures. As in most decapod egg lipids are the main component for energy production and protein is the most abundant component (Holland, 1978).

\section{Fisheries and aquaculture}

The first studies in Mexico started in the 1970's; but most are informal reports, anecdotal or with conflicting results (Mercado, 1959; Rodríguez de la Cruz, 1965, 1967; Arana-Magallón, 1974). Some formal studies focused on the potential of this species for cultivation have been done but still not enough to support cultivation beyond experimental assays. Some assays have been done in captivity by Ruiz et al. (1996) or Arana \& Ortega (2004), finding fast growth of juveniles kept at low densities in tanks. García-Guerrero \& Apun-Molina (2008) studied how density and shelters affect survival and growth of juveniles. Prawns kept at low density with a shelter grew faster and survived longer. The last authors stated that one disadvantage is that $M$. americanum is a territorial prawn and often aggressive, a behavior that is enhanced in large specimens. Cannibalism is not rare and recently molted specimens are the most likely preys. Larval cultivation of $M$. americanum has been performed up to the postlarval stage, although very poor survival has been 
attained (Arana-Magallón, 1974; Monaco, 1975; Holtschmit \& Pfeiler, 1984; Díaz-Monge et al., 2001; Yamasaki-Granados et al., 2013). Monaco (1975) was the first to complete all stages of larval development (53 days at $29 \pm 5^{\circ} \mathrm{C}$ ) but with very poor survival. Yamasaki-Granados et al. (2013) state that recently hatched larvae $(0-72 \mathrm{~h})$ can eat dead or slow nauplii; but apparently, they do not fulfill nutritional requirements and they seem to be hard to catch for such larvae. In addition, Díaz-Monge et al. (2001) reported that Artemia nauplii ( $24 \mathrm{~h}$ after hatching) are larger than M. americanum larvae; therefore, they are not suitable as food during early stages of development. YamasakiGranados et al. (2013) stated that the most important tasks for raising larvae include monitoring physical and chemical parameters of the water, breeding quality of the adults, and the use of high nutritional value and small in size live food, at least during the first half of development. To be effective, the food must be easy to be recognized and captured (Yamasaki-Granados et al., 2013). These last authors suggest that feeding with rotifers, which can tolerate brackish water, might be an option to overcome this problem, in addition to monitoring strictly temperature and salinity. In fact, Yamasaki-Granados et al. (2013) offer a table of salinities for cultivating the larvae of this prawn. Macrobrachium larvae can be cultivated with success in clear fresh water (Daniels et al., 1992), but including microalgae is also common. From previous research on cultivating prawn larvae, microalgae are recognized for their role in removing wastes and controlling light and dissolved $\mathrm{O}_{2}$ to benefit larvae (Lober \& Zeng, 2009; Nunes et al., 2011; Yamasaki-Granados et al., 2013). Most recently, a study by Rojo-Cebreros et al. (2013) found that $M$. americanum is a good companion for tilapia fish and does not interfere with fish production.

In relation to fisheries and because of their biological cycle, $M$. americanum prawns are exposed to year-round overfishing and there is an established local market during the whole year, since this prawn is fished for local consumption or sold to restaurants close to the fishing area. There are no records on its fisheries and most information available is informal and comes from fishermen. In most places, populations have severely declined or disappeared by overfishing, illegal fishing practices, pollution, alteration of habitat, and intensive collection of seed and juveniles since these are also cached, dried, and sold as food for ornamental fish (García-Guerrero et al., 2013). It is possible that this last practice hinders new population recruitment, but its real impact has not been examined yet.

\section{Main concerns that are poorly explored}

Studies on growth rate, survival, mortality, as well as the detailed effect of most environmental parameters that may affect this prawn either in the wild or under culture are lacking. However, the most urgent topic that should be addressed is the development of larval culture techniques. Production of larvae is perhaps the most critical issue before considering a species as a good candidate for commercial cultivation. Monaco (1975) was perhaps the first to obtain the larval development, but with poor survival. Ever since, few studies have addressed this particular issue. Highquality, laboratory-reared larvae are essential because successful and profitable production requires a constant supply of high quality juveniles for stocking, since no commercial activity can rely forever on wild larvae or postlarvae (New, 2005, 2009; New \& Nair, 2012); hence, commercial production will eventually fail (Hongtuo et al., 2012; Yamasaki-Granados et al., 2013). Previous studies on larval development provide clues on larval management and feeding. Small larvae make the cultivation of $M$. americanum a difficult challenge. In recent studies, such as those of YamazakiGranados et al., 2013, the fry or seed supply was the most urgent focus, and this remains so. Production technology for larvae has to be standardized before constant mass production of juvenile prawns can be achieved. A well developed protocol for rearing juveniles in the hatchery or in the laboratory is necessary because gathering of wild juveniles does not guarantee constant, homogeneous, and high quality fry for stocking (Gopal, 2002). Success strongly depends on a ready supply of fry from hatcheries, which often is the hardest bottleneck to overcome and one of the main requisites before introducing any aquatic species to commercial cultivation. In spite of previous studies that have advanced on $M$. americanum larval development, there is no reliable technique for cultivating these larvae (Yamasaki-Granados et al., 2013). The use of antibiotics to prevent or control infectious diseases is also understudied, as well as that of immune stimulants and probiotics in food and water (Yamasaki-Granados et al., 2013). These products must be strictly controlled and supervised prior to their application, because they can produce unwanted effects during cultivation or on the environment (Gatesoupe, 1999; Yamasaki-Granados et al., 2013).

Other considerations include the physiological consequences on prawns exposed to high levels of nitrogenous wastes (Romano \& Zeng, 2013). Specific diets have not been prepared for this prawn, even though its nutritional requirements are similar to that of other prawns. Behavior and genetic studies that lead to selection of docile, resistant, and fast-growing lineages for aquaculture are always required (Nguyen et al., 2009), but none have been made in this species, and there are no studies about mono-sex cultivation. Social structure and behavioral studies are also necessary for 
assessing maximum densities and combinations of sizes, sex, and age classes to control crowding. Hybridization with other Macrobrachium species, marketing potential of the species out of its native area, and tolerance to viral or bacterial infections are also unknown and required. In relation to reproduction issues, berried females availability is of major importance. They can be captured from the wild, but quality may be uncertain and stress can inhibit the females from attending the grooming behavior of their egg masses (García-Guerrero, 2009). In turn, this will lead to egg loss or infections causing low hatching rates (García-Guerrero, 2009). Because of this, research must include laboratory-produced berried females. Mating in captivity is easy in prawns, despite cannibalism of soft-shelled females but a maturation diet has not been developed yet for this species (GarcíaGuerrero \& Apun-Molina, 2008). Other reproduction issues, such as all the environmental cues that influence gonadal activity (Ross \& Beveridge, 1995) are still unknown. In relation to grow-out, for juveniles or adults under cultivation, balanced pelletized diets fundamental for fast grow-out have not been developed (D'Abramo et al., 1997). Since feeding is the most expensive cost of production, $40-60 \%$ of the total budget (Akiyama et al., 1992), studies on high quality but cheap balanced diets are required.

Aggressiveness and cannibalism are other main concerns; crowding stresses prawns, making them aggressive and prone to infections, parasites, or loss of appetite (Ross \& Beveridge, 1995). This is worse among aggressive prawns, and $M$. americanum is particularly aggressive, with well-developed territorial behavior, particularly adult males (García-Guerrero \& Apun-Molina, 2008). During confinement, crowding, lack of shelters, and inappropriate food will cause larger prawns to seriously injure or kill smaller ones (García-Guerrero \& Apun-Molina, 2008). During postmolt, mortality rates increase, even if appropriate food and shelters are provided. To minimize this problem, research on strains with docile behavior must be performed, or techniques focused to deal with this issue must be developed.

Other issues must be studied once the basic features limiting cultivation technology are clarified. Specific cultivation techniques are required, such as the use of all-male stock, strains that grow fast, use of cheap local materials and products that are compatible with aquaculture. Legislation policies, management, weather, availability and quality of water, road conditions, electricity, communication, and distance from the final market are other secondary issues to determine the best areas for native prawns cultivation. In the case of marketing, the adoption of native species new to aquaculture into semi-intensive and intensive produc- tion requires the generation of a vast body of biotechnical information. This enterprise should be executed after exploring marketing chances of success. In some situations, large-scale production for processing and shipping may not be economically competitive with products imported from Asia (Tidwell, 2012). Finally, outdoor cultivation studies are needed since growth and performance in ponds have neither been investigated.

\section{DISCUSSION}

Macrobrachium americanum's potential for culture is still to be clarified, but most cultivation techniques and management strategies could be adapted from studies and manuals dedicated to other species, such as $M$. rosenbergii (New, 2005) or M. tenellum (VegaVillasante et al., 2011). These studies state that native prawns cultivation could be profitable in the corresponding region. It provides working opportunities to low-income farmers, with a product that can give them a high return. It has happened in countries such as Thailand or India, in which the culture of prawns is common as part of an extensive strategy that implies the use of wild berried females or wild juveniles stocked in cheap facilities and managed by families (Na-Nakorn \& Jintasataporn, 2012). In China, breeding and larval rearing of $M$. nipponense and grow-out production has been developed (Hongtuo et al., 2012). Research institutions, in the late 1980's, have also standardized in India mass production of prawn juveniles of M. malcolmsonii and M. gangeticum, under controlled culture schemes based on seed production technology (Nair \& Salin, 2012). Since 1996, various research groups in Brazil have worked with the experimental culture of M. amazonicum (e.g., MoraesValenti \& Valenti, 2007, 2009). After a hard starting with some unsuccessful results, basic technology is now available for all phases of production of this latter species. In addition, in Brazil, hatchery studies of $M$. carcinus provide promising results (Rocha et al., 2011). All those previous reports suggest that culture in a profitable scheme is possible with $M$. americanum, or with other native species if proper techniques are developed.

Macrobrachium prawns culture may have additional advantages: they are a good option for aquaculture in tropical and semi-tropical regions because all phases of cultivation can be done year round since they can be stocked or harvested at any time, and two or three grow-out cycles per year are possible, with good profits (Tidwell, 2012). These prawns can be raised without access to saltwater or expensive coastal lands and they do not require much fishmeal in their 
diet (Tacon \& Metian, 2008). For example, Tidwell (2012) evaluated freshwater prawns for sustainability on the following criteria: 1) Use of marine resources, 2) risk of escape of cultivated animals to the wild, 3 ) risk of disease and parasite transfer to wild populations, 4) risk of pollution and habitat degradation, and 5) effective management. Freshwater prawns were rated as "low environmental concern" in the five categories and were designated as a "best choice". He stated that prawns were one of the most sustainable seafood choices available, which means their cultivation could be environmentally safe. In fact, Ross \& Beveridge (1995) mentioned that aquaculture of native species could be suitable in economic, biotechnical, and environmental terms. Of course, research on native species needs to be analyzed through different criteria prior to commercial production. If properly cultivated, markets could include, in addition to human consumption, ornamental trade and bait (AlmeidaMarques \& Moraes-Valenti, 2012). In addition, aquaculture may help to protect a species from overfishing by giving additional product supply (Bowles et al., 2000). For example, wild populations of $M$. rosenbergii were overfished in Thailand, and expansion of agriculture, habitat destruction, and water pollution led to a rapid populations decline (Na-Nakorn \& Jintasataporn, 2012). However, since 1977, prawnbreeding technology for this species has improved; it has been cultivated in Thailand and thereafter annual production has increased and wild populations are recovering.

Some areas of Mexico and shores all along western Latin America are appropriate for the cultivation of $M$. americanum, because they provide land areas with suitable water and weather conditions. In addition, juveniles produced from hatchery-reared larvae may help restore wild populations if proper measures to preserve genetic diversity are included in those programs. However, to introduce prawn farming as an option is hard not only because of lack of technologies, but also because in certain areas active fishing still provides easily catch product. This means that people of those regions will prefer to capture the prawns for consumption or for sale in the wild instead of working with culture techniques, which implies more investment and more work. To make it worse, most countries where $M$. americanum lives have no fishery policies, or have policies that are not enforced. Specific social and economic factors are also involved, depending on the region.

Since biodiversity must be preserved, development of sustainable aquaculture requires consideration of an ecosystem approach (Ross et al., 2008, MartínezCórdova et al., 2009), which can be reached only working with native species in both culture and conservation programs. If possible, conservation programs including all research areas should be financed or executed based on restoration programs of this living resource. Since this task can be expensive and lengthy, it is important to focus on the most important factors (Ross et al., 2008). Ross \& Beveridge (1995) considered the most important issues to be classified with these criteria:

1) Basic biology: natural habitat and habits, basic ecology and functional biology.

2) Environmental physiology: optimum temperature, salinity and photoperiod for growth and survival.

3) Closed reproductive cycle: developing the conditions for the whole cycle in captivity.

4) Nutrition: identification of natural feeding strategy and food items, feeds, and diets.

5) Growing systems: development of appropriate physical and farming systems for the species, its environment and the socio-economic status of the communities.

Of these, issues 1 and 2 are mostly known for $M$. americanum, whereas issue 3 (part of larval studies) is suggested as urgent and having priority over issues 4 and 5. Knowledge-oriented research on nutritional requirements at the various stages of life and on behavioral aspects (social stratification in pond culture under high densities) must be carried out simultaneously with studies identified as having the highest priority. Additionally, cultivation of $M$. carcinus, a co-generic species with $M$. americanum but distributed on the Atlantic side of the tropical Americas, may prove feasible if equivalent attention is given.

\section{CONCLUSIONS}

Current knowledge of M. americanum cultivation is not sufficient to support cultivation beyond research purposes. The main problem that prevents cultivation of $M$. americanum, on a commercial scale, is the requirement of strict water quality control. Aggressiveness seems to be the other major obstacle. To consider the species as a commercial culture option is still not clear given its cannibalistic behavior and the lack of proper larval production technologies. Because of this, the case of M. americanum as a good option for sustainable aquaculture should first be aimed at conservation purposes since it needs special attention as a natural resource that has to be protected. Future studies must consider intraspecific variation in lifehistory traits of separate populations, which differ in physiological responses to salinity, egg size, feeding, 
and other variable larval traits. Outdoor cultivation assays in ponds and managed with different techniques are required to appraise production possibilities and limitations.

\section{ACKNOWLEDGEMENTS}

M. García Guerrero thanks the Secretaría de Investigación y Posgrado and Comisión de Fomento de Actividades Académicas del Instituto Politécnico Nacional for their financial support. E. Cortes thanks projects CB201/156252, 2014/227565, CONACYTMINCYT-MX/09/07 and AMEXCID CTC/06038/14. Ingrid Mascher edited the final version of this document.

\section{REFERENCES}

Adhicari, S., A. Ahmad, K. Naqvi, C. Pani, B. Pillai, K. Jena \& N. Sarangi. 2007. Effect of manganese and iron on growth and feeding of juvenile giant river Prawn, Macrobrachium rosenbergii (De-Man). J.World Aquacult. Soc., 38(1): 161-168.

Akiyama, D., M. Dominy \& G. Lawrence. 1992. Penaeid shrimp nutrition. In: A. Fast \& W. Lester (eds.). Marine shrimp culture: principles and practices. Elsevier, Amsterdam, pp. 535-568.

Almeida-Marques, H. \& P. Moraes-Valenti. 2012. Current status and prospects of farming the giant river prawn Macrobrachium rosenbergii (De Man, 1879) and the Amazon River prawn Macrobrachium amazonicum (Heller, 1862) in Brazil. Aquacult. Res., 43: 984-992.

Arana-Magallón, F. 1974. Experiencias sobre el cultivo del langostino Macrobrachium americanum Bate, en el noroeste de México. Simposio FAO/Carpas sobre Acuacultura en América Latina. Montevideo, Uruguay, 26 November-2 December, 1974. Available on line. [http://www.fao.org/docrep/005/ac866s/AC 866S19.htm].

Arana, F. \& A. Ortega. 2004. Rearing of the cauque prawn under laboratory conditions. N. Am. J. Aquacult., 66: 158-161.

Bauer, R. 2011. Amphidromy and migrations of freshwater shrimps. II. Delivery of hatching larvae to the sea, return of juvenile upstream migration, and human impacts. New Front. Crust. Biol., 157: 168188.

Bowles, D., K. Aziz \& C. Knight. 2000. Macrobrachium (Decapoda: Caridea: Palaemonidae) in the contiguous United States: a review of the species and an assess- ment of threats to their survival. J. Crustacean Biol., 20: $158-171$.

D`Abramo, L., R. Conklin \& D. Akiyama. 1997. Crustacean nutrition advances in world aquaculture. World Aquaculture Society, Baton Rouge, 6: 587 pp.

Daniels, W., L. D`Abramo \& L. Parseval. 1992. Design and management of a close recirculated clear water hatchery system for freshwater Macrobrachium prawns. J. Shellfish Res., 11: 65-73.

Díaz-Monge, F., M. Díaz \& R. Rodríguez. 2001. Producción larval de camarón de río nativo, Macrobrachium americanum en laboratorio. Centro de Estudios del Mar y Acuicultura, Guatemala City, 78 pp.

García-Guerrero, M. 2009. Proximate biochemical variations in eggs of the prawn Macrobrachium americanum (Bate, 1869) during its embryonic development. Aquacult. Res., 40: 575-581.

García-Guerrero, M. 2010. Effect of temperature on consumption rate of main yolk components during the embryo development of the prawn Macrobrachium americanum (Crustacea: Decapoda: Palaemonidae). J. World Aquacult. Soc., 41: 84-92.

García-Guerrero, M. \& P. Apun-Molina. 2008. Density and shelter influence the adaptation to wild juvenile cauque prawns Macrobrachium americanum to culture conditions. N. Am. J. Aquacult., 70: 343-346.

García-Guerrero, M. \& M. Hendrickx. 2009. External description of the embryonic development of the prawn Macrobrachium americanum based on the staging method. Crustaceana, 82: 1413-1422.

García-Guerrero, M., J. Orduña-Rojas \& E. CortesJacinto. 2011. Oxygen consumption of the prawn Macrobrachium americanum (Bate, 1868) over the temperature range of its native environment and in relation to its weight. N. Am. J. Aquacult., 73: 320326.

García-Guerrero, M., F. Becerril-Morales, F. VegaVillasante \& L. Espinosa-Chuarand. 2013. Los langostinos del género Macrobrachium con importancia económica y pesquera en América Latina: conocimiento actual, rol ecológico y conservación. Lat. Am. J. Aquat. Res., 41: 651-675.

Gatesoupe, J. 1999. The use of probiotics in aquaculture. Aquaculture, 180: 147-165.

Goda, A. 2008. Effects of dietary protein and lipid levels and protein-energy ratio on growth indices, feed utilization and body composition of freshwater prawn, Macrobrachium rosenbergii (de Man, 1879) post larvae. Aquacult. Res., 39: 891-901.

Grave, S., Y. Cai \& A. Anker. 2008. Global diversity of shrimps (Crustacea: Decapoda: Caridea) in freshwater. Hydrobiologia, 595: 287-293. 
Gopal, P. 2002. The potential of the freshwater giant prawn Macrobrachium rosenbergii culture in Muktagachha Upazila using GIS as a tool. Master Thesis, Bangladesh Agricultural University, Mymensingh, $270 \mathrm{pp}$.

Hernández, L., G. Murugan, G. Ruiz \& A. Maeda. 2007. Freshwater shrimp of the genus Macrobrachium (Decapoda Paleamonidae) from the Baja California Peninsula, Mexico. J. Crustacean Biol., 27: 351-369.

Holthuis, L.B. 1980. FAO species catalogue. Vol.1. Shrimps and prawns of the world. An annotated catalogue of species of interest to fisheries. FAO Fish. Synop., 125(1): 1-271 pp.

Holland, D. 1978. Lipid reserves and energy metabolism in the larvae of benthic marine invertebrates. In: D.C. Malins (ed.). Biochemical and biophysical perspectives in marine biology. Academic Press, Seattle, pp. 85-123.

Horne, F. \& S. Besser.1977. Distribution of river shrimp in the Guadalupe and San Marcos Rivers of central Texas, U.S.A. (Decapoda, Caridea). Crustaceana, 33: 56-60.

Holtschmit, K. \& E. Pfeiler. 1984. Effect of salinity on survival and development of larvae and postlarvae of Macrobrachium americanum Bate (Decapoda, Palaemonidae). Crustaceana, 46: 23-28.

Hongtuo, F., S. Jiang \& X. Yiwei. 2012. Current status and prospects of farming the giant river prawn (Macrobrachium rosenbergii) and the oriental river prawn (Macrobrachium nipponense) in China. Aquacult. Res., 43: 993-998.

Kutty, M.N. 2005.Towards sustainable freshwater prawn aquaculture-lessons from shrimp farming, with special reference to India. Aquacult. Res., 36: 255-263.

Lober, M. \& C. Zeng. 2009. Effect of microalgae concentration on larval survival, development and growth of an Australian strain of giant freshwater prawn Macrobrachium rosenbergii. Aquaculture, 289: 95-100.

Martínez-Córdova, L.R., M. Martínez-Porchas \& E. Cortés-Jacinto. 2009. Camaronicultura mexicana y mundial: ¿Actividad sustentable o industria contaminante? Rev. Int. Cont. Amb., 25: 181-196.

Mercado, P. 1959. Proyecto para una estación rústica dedicada al cultivo de los langostinos. Bol. Piscicult. Rural Secret. Ind. Com., México, 6: 5-6.

Monaco, G. 1975. Laboratory rearing of larvae of the palaemonid shrimp Macrobrachium americanum (Bate). Aquaculture, 6: 369-375.

Moraes-Valenti, P. \& W. Valenti. 2007. Effect of intensification on grow out of the Amazon River prawn, Macrobrachium amazonicum. J. World Aquacult. Soc., 38: 516-526.
Moraes-Valenti, P. \& W. Valenti. 2009. Culture of the Amazon River prawn Macrobrachium amazonicum. In: M.B. New, W.C. Valenti, J.H. Tidwell, L.R. D'Abramo \& M.N. Kutty (eds.). Freshwater prawns: biology and farming. Wiley-Blackwell, Oxford, pp. 485-501.

Nair, M. \& K. Salin. 2012. Current status and prospects of farming the giant river prawn Macrobrachium rosenbergii (De Man) and the monsoon river prawn Macrobrachium malcolmsonii (H.M. Edwards) in India. Aquacult. Res., 43: 999-1014.

Na-Nakorn, U. \& O. Jintasataporn. 2012. Current status and prospects of farming the giant river prawn (Macrobrachium rosenbergii de Man 1879) in Thailand. Aquacult. Res., 43: 1015-1022.

New, M. 2005. Freshwater prawn farming: global status, recent research and a glance at the future. Aquacult. Res., 36: 210-230.

New, M. 2009. History and global status of freshwater prawn farming In: M.B. New, W.C. Valenti, J.H. Tidwell, L.R. D'Abramo \& M.N. Kutty (eds.). Freshwater prawns: biology and farming. WileyBlackwell, Oxford, 560 pp.

New, M. \& M. Nair. 2012. Global scale of freshwater prawn farming. Aquacult. Res., 43: 960-969.

Nguyen, M., W. Ponzoni, N. Hong Nguyen, N. Thanh, A. Barnes \& B. Mather. 2009. Evaluation of growth performance in a dialed cross of three strains of giant freshwater prawn (Macrobrachium rosenbergii) in Vietnam. Aquaculture, 287: 75-83.

Nunes, A., C. Sa \& H. Sabry-Neto. 2011. Growth performance of the white shrimp, Litopenaeus vannamei fed on practical diets with increasing levels of the Antarctic krill meal Euphausia superba reared in clear-versus green-water culture tanks. Aquacult. Nutr., 17: 511-520.

Piyan, B., A. Law \& S. Cheah 1985. Toxic levels of mercury for sequential larval stages of Macrobrachium rosenbergii de Man. Aquaculture, 46: 353359.

Rocha, D., L. Santos, F. Branco, J. Lima \& E. Correia. 2011. Postlarvae survival of freshwater prawn Macrobrachium carcinus (Linnaeus, 1758) reared under different feeding protocols, Abstracts of the Asian Pacific Aquaculture 2011, 17-20 Jan 2011, Kochi, World Aquaculture Society, Baton Rouge, pp. 92.

Rodríguez de la Cruz, C. 1965. Contribución al conocimiento de los palemónidos de México, Secretaría de Industria y Comercio, Dirección General de Pesca e Industrias conexas. Contrib. Inst. Nac. Inv. Biol.-Pesq. II Congreso Nacional de Oceanografía, pp. 7-11. 
Rodríguez de la Cruz, C. 1967. Contribución al conocimiento de los palemónidos de México, Palemónidos del Golfo de California con notas sobre la biología de Macrobrachium americanum Bate. An. Inst. Nac. Invest. Biol.-Pesq., 8: 157 pp.

Rojo-Cebreros, A., M. García-Guerrero, A. Santamaría \& P. Apun. 2013. A preliminary assay on the mixed culture of red Florida tilapia and freshwater prawn Macrobrachium americanum stocked in outdoor tanks at different tilapia densities. Agr. Sci., 4(7): 345-352.

Romano, N. \& Ch. Zeng. 2013. Toxic effects of ammonia, nitrite, and nitrate to decapod crustaceans: a review on factors influencing their toxicity, physiological consequences, and coping mechanisms. Rev. Fish. Sci., 21: 1-21.

Ross, L. \& M. Beveridge.1995. Is a better strategy necessary for development of native species for aquaculture? A Mexican case study. Aquat. Fish. Manage., 26: 539-547.

Ross, L., C. Martínez-Palacios \& E. Morales. 2008. Developing native fish species for aquaculture: the interacting demands of biodiversity, sustainable aquaculture and livelihoods. Aquacult. Res., 39: 675683.

Ruiz, M., J. Peña \& Y. López. 1996. Morfometría, época reproductiva y talla comercial de Macrobrachium americanum (Crustacea: Palaemonidae) en Guanacaste, Costa Rica. Rev. Biol. Trop., 44: 127-132.

Shinn-Pyng, Y., S. Tzeng-Gan, C. Chin-Chyuan, C. Winton \& K. Ching-Ming, 2005. Effects of an organophosphorus insecticide, trichlorfon on hematological parameters of the giant freshwater prawn, Macrobrachium rosenbergii (de Man). Aquaculture, 243: 383-392.

Schwantes, V., J. Diana \& Y. Yang. 2009. Social, economic, and production characteristics of giant river prawn Macrobrachium rosenbergii culture in Thailand. Aquaculture, 287: 120-127.

Somoza, G. \& L. Ross. 2011. Introduction to the special issue on development of native species for aquaculture in Latin America II. Aquacult. Res., 42: 737-738.
Tacon, A. \& M. Metian. 2008. Global overview on the use of fish meal and fish oil in industrially compounded aquafeeds: trends and future prospects. Aquaculture, 285: 146-158.

Tidwell, J. 2012. Current status and prospects of farming the giant river prawn (Macrobrachium rosenbergii De Man, 1879) in the United States. Aquacult. Res., 43: 1023-1028.

Tidwell, J. \& L. D’Abramo. 2010. Grow-out systemsculture in temperate climates. In: M.B. New, W.C. Valenti, J.H. Tidwell, L.R. D’Abramo \& M.N. Kutty (eds.). Freshwater prawns: biology and farming. Wiley-Blackwell, Oxford, pp. 180-194.

Valenti, W. \& P. Moraes-Riodades. 2004. Freshwater prawn farming in Brazil. Global Aquacult. Advocate, 7: 52-53.

Valenti, W. \& M. New. 2000. Grow out systemsmonoculture. In: M.B. New \& W.C. Valenti (eds.). Freshwater prawn culture: the farming of Macrobrachium rosenbergii. Blackwell Scientific, Oxford, pp. 157-176.

Vega-Villasante, F., L. Espinosa-Chaurand, S. YamasakiGranados, E. Cortés-Jacinto, M. García-Guerrero, A. Cupul-Magaña, H. Nolasco-Soria \& M. GuzmánArroyo. 2011. Acuicultura del langostino Macrobrachium tenellum: engorda en estanques semi rústicos. Universidad de Guadalajara y Consejo Estatal de Ciencia y Tecnología del Estado de Jalisco, 140 pp.

Wahab, A., A. Al-Nahid, A. Nesar Ahmed, M. Haque \& K. Mahmudul. 2012. Current status and prospects of farming the giant river prawn Macrobrachium rosenbergii (De Man) in Bangladesh. Aquacult. Res., 43: 970-983.

Yamasaki-Granados, S., M. García-Guerrero, F. VegaVillasante, F. Castellanos-León, R. Cavalli \& E. Cortés-Jacinto. 2013. Experimental culture of the river prawn Macrobrachium americanum larvae (Bate, 1868), with emphasis on the stocking density effect on survival. Lat. Am. J. Aquat. Res., 41(4): 793-800.

Received: 1 May 2015; Accepted: 7 August 2015 